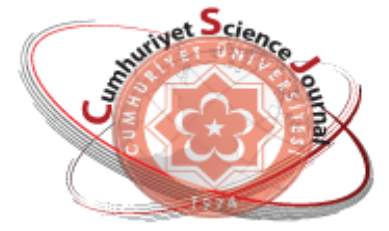

e-ISSN: $2587-246 X$

ISSN: $2587-2680$

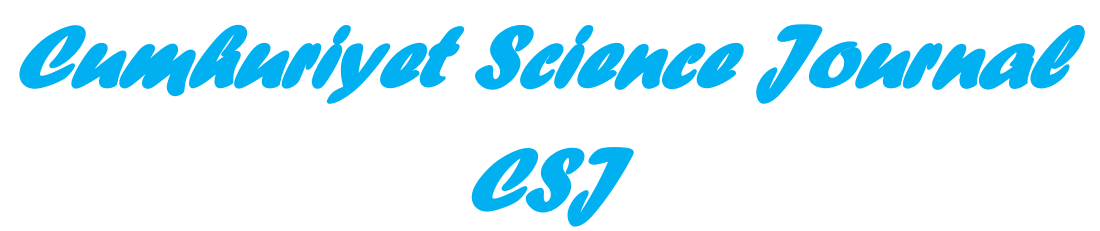

Cumhuriyet Sci. J., Vol.39-2(2018) 366-374

\title{
Thickness Dependent Dielectric Loss of Plasma Poly (Ethylene Oxide) Films
}

\author{
Hulusi Kemal ULUTAS \\ Istanbul University, Science Faculty, Physics Department, İstanbul, TURKEY \\ http://dx.doi.org/10.17776/csj.399267
}

Received: 27.02.2018; Accepted: 30.03.2018

\begin{abstract}
Dielectric properties of plasma poly (ethylene oxide) (pPEO) thin film samples were investigated at room temperature. The thin film samples with different thicknesses were deposited by plasma assisted physical vapor deposition (PAPVD) technique at $5 \mathrm{~W}$ plasma discharge power. The thicknesses were 20, 100, $250,500 \mathrm{~nm}$. It was observed that dielectric constant increases with increasing thickness. The relaxation times determined by dielectric loss-frequency relation, shift toward higher frequencies with increasing thickness. In addition film thickness, heating processes were defined as another parameter. By this purpose, thin film samples were heated and cooled, respectively. It was observed that maxima and minima of dielectric loss at cooling process take place at lower frequencies in comparison with frequencies at which maxima and minima were detected at heating process. These results may show the effect of dead layer at thinner films. After heating process, it was observed from behavior of dielectric constant and dielectric loss that the crosslinking density increases by heating effect. This effect may cause additional reactions between free radicals which are production of PAPVD. Moreover, dynamic glass transition temperatures were calculated. These temperatures prove the effect of dead layer approximation.
\end{abstract}

Keywords: Plasma poly (ethylene oxide), thin film, dielectric properties, dynamic glass transition temperature.

\section{Plazma Poli(etilen oksit) Filmlerin Dielektrik Kaybının Kalınlığa Bağlılı̆ğ}

Özet: Plazma poli (etilen oksit) (pPEO) ince film örneklerinin dielektrik özellikleri oda sıcaklığında incelendi. Farklı kalınlıklardaki ince film örnekleri, $5 \mathrm{~W}$ plazma boşaltma gücünde plazma destekli fiziksel buhar depozisyonu (PAPVD) tekniği ile elde edildi. Film kalınlıkları 20, 100, 250, 500 nm'dir. Artan film kalınlığı ile dielektrik sabitinin arttı̆̆ı gözlenmiştir. Dielektrik kayıp ve frekans ilişkisi ile belirlenen relaksasyon zamanları, artan kalınlık ile daha yüksek frekanslara kaymaktadır. Film kalınlığına ilaveten, 1sıtma süreçleri bir diğer parametre olarak tanımlandı. Bu amaçla, ince film örnekleri sırasıyla isıtılmış ve soğutulmuştur. Soğutma sürecindeki dielektrik kaybın maksimum ve minimumunun, isıtma sürecindeki maksimum ve minimumunun belirlendiği frekanslardan daha alçak frekanslarda meydana geldiği gözlenmiştir. Bu sonuçlar, daha ince filmlerde ölü tabakanın etkisini gösterebilir. Isıtma sürecinden sonra, dielektrik sabiti ve dielektrik kayıp davranışından, çapraz bağlanma yoğunluğunun 1sıtma etkisiyle arttığı gözlenmiş̧tir. Bu etki PAPVD'nin ürünü olan serbest radikaller arasında ek tepkimelere neden olabilir. Ayrıca dinamik camsı geçiş sıcaklıkları hesaplandı. Bu sıcaklıklar ölü tabaka yaklaşımı etkisini ispatlamaktadır.

Anahtar Kelimeler: Plazma poli (etilen oksit), ince film, dielektrik özellikler, dinamik camsı geçiş sıcaklığı.

\footnotetext{
* Corresponding author. Email address: hku@istanbul.edu.tr

http://dergipark.gov.tr/csj C2016 Faculty of Science, Cumhuriyet University
} 


\section{INTRODUCTION}

In recent days, polymers became row materials in electrical and electronic devices as insulating materials [1-7]. Poly (ethylene oxide) is an attractive member of this family with its biological non-fouling properties [8]. Poly (ethylene oxide) can have developed and modified properties as homogeneity, free from pinholes, water insolubility, high electrical resistance, chemical stability, high cross-linking density, good adhesion and thermal stability by plasma polymerization [7, 9-12]. High crosslinking density is one of important reasons of good non-fouling properties. Crosslinking density can be investigated by some techniques such as differential scanning calorimetry (DSC), X-Ray photoelectron spectrometry (XPS), Fourier transformation infrared spectrometry (FTIR) and mass spectrometry (MS). Especially DSC is a useful technique to analyze the crosslinking and its result via detecting glass transition temperature. Although the technique is a good way to determine glass transition and change of crosslinking density, it unable to analyze the glass transition temperature depending on the thickness of plasma polymer thin film. Dielectric spectroscopy can be used to determine the glass transition temperature via dielectric properties [11-14]. In this work, the dielectric properties of plasma poly (ethylene oxide) thin films deposited at 5W plasma and at various thicknesses as 20, 100, 250, $500 \mathrm{~nm}$ were analyzed. In literature it was found that the thickness dependent dielectric properties of plasma poly (ethylene oxide) thin films were not investigated. In addition to investigation of dielectric properties, we aimed to determine the glass transition temperature and analyze the effect of dead layer which is a result of good adhesion of crosslinked surfaces onto substrates.

\section{EXPERIMENTAL}

Plasma PEO thin film samples were deposited between alumina $(\mathrm{Al})$ thin film electrodes by plasma assisted physical vapor deposition (PAPVD) method. Al thin film electrodes were deposited by thermal evaporation method. Thin film samples were deposited on glass substrates. All samples were deposited at $5 \mathrm{~W}$ radio-frequency (RF) plasma power in different thickness as $20 \mathrm{~nm}, 100 \mathrm{~nm}, 250 \mathrm{~nm}$, and 500 nm. Dielectric spectroscopy measurements were performed by Alpha- $\mathrm{N}$ high frequency Impedance analyzer (Novocontrol Co.) in frequency range between $0.1 \mathrm{~Hz}$ and $10^{7} \mathrm{~Hz}$ and temperature range between $173 \mathrm{~K}$ and 353 $\mathrm{K}$.

\section{RESULTS and DISCUSSION}

It is known from literature that the vapor of PEO undergoes a fragmentation under the influence of plasma discharge. This fragmentation causes production of free radicals and oligomers as $\mathrm{CHO}+, \mathrm{CH}_{3} \mathrm{O}+, \mathrm{C}_{2} \mathrm{H}_{5} \mathrm{O}+$, $\mathrm{C}_{3} \mathrm{H}_{7} \mathrm{O}+$ ions and $\mathrm{CH}_{3} \mathrm{COH}, \mathrm{CH}_{3} \mathrm{O} \mathrm{CH}_{3}, \mathrm{CH}_{3}$ $\mathrm{CH}_{2} \mathrm{OH}, \mathrm{CO}_{2}$ groups $[15,16]$. Oligomers and free radicals re deposited on substrate randomly and a new structure so called plasma polymer with high crosslinking is produced. Frequency dependence of dielectric constant $\left(\varepsilon^{\prime}\right)$ for different thicknesses at first cooling process is presented in Fig. 1 a, b, c, d. For a comparison, frequency dependence of $\varepsilon^{\prime}$ for different thicknesses at second cooling process is presented in Fig.2 a, b, c, d. 

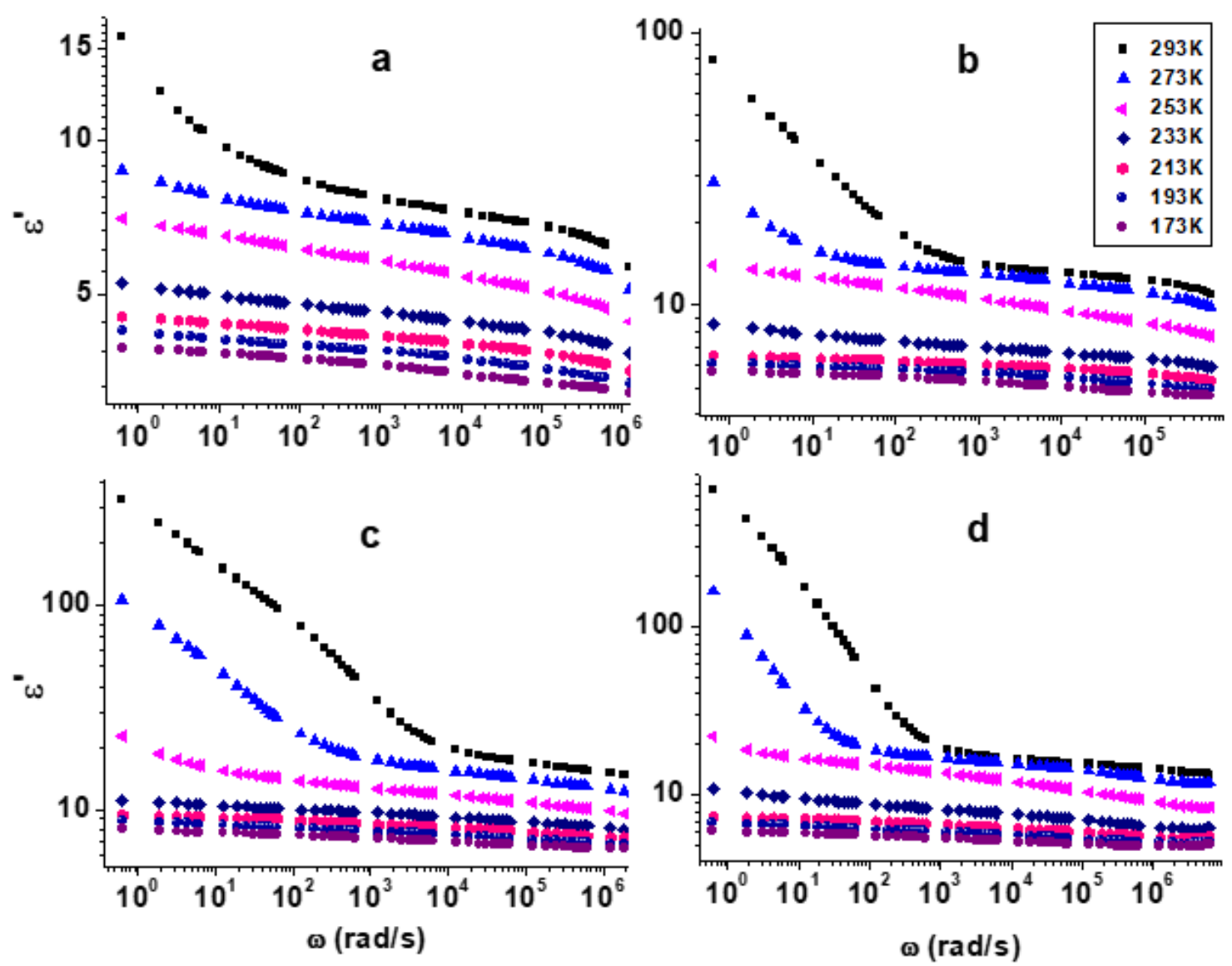

Figure 1. Frequency dependence of dielectric constant $\left(\varepsilon^{\prime}\right)$ for a) $20 \mathrm{~nm}$, b) $100 \mathrm{~nm}$, c) $250 \mathrm{~nm}$, d) $500 \mathrm{~nm}$ at first cooling process.

Dielectric constant decreases with increasing frequency as shown in Fig.1. This behavior can be attributed that the polymer back bone and side chains can't follow the applied electric field toward high frequencies. Thus, the polarization in structure decreases and proportionally the dielectric constant decreases [17]. Additionally, the dielectric constant increases with increasing temperature as shown in Fig.1. Since increasing temperature may cause increase in motion of polymer back bone and side chains, the polarization increases [18]. Increasing thickness shows increasing effect on dielectric constant as shown in Fig.1. The number of dipoles increases with increasing thickness [19]. In both temperature processes it is observed that there are two relaxation regions in the investigated frequency range. The mechanism observed at low frequency side and at high temperatures is called as $\alpha$-relaxation which is attributed to phase transition of structure from rubber state to glassy state. The other mechanism observed at high frequency side and at low temperatures is called as $\beta$ relaxation which is attributed to dipolar fluctuation of side chains [20-26]. 

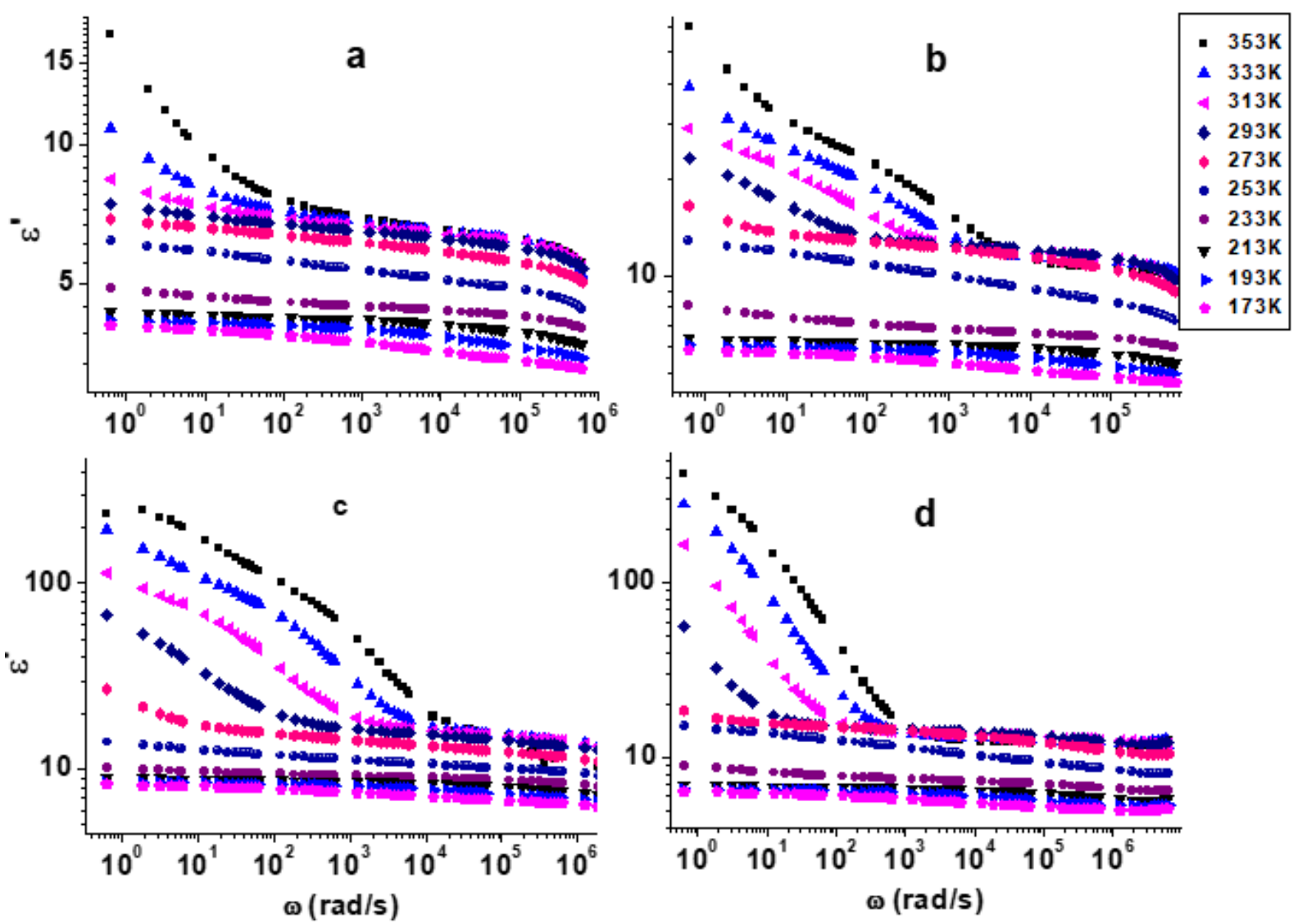

Figure 2. Frequency dependence of dielectric constant ( $\left.\varepsilon^{\prime}\right)$ for a) $20 \mathrm{~nm}$, b) $100 \mathrm{~nm}$, c) $250 \mathrm{~nm}$, d) $500 \mathrm{~nm}$ at second cooling process.

It can be detected that the dielectric constants measured at first cooling are greater than the dielectric constants measured at second cooling. It is expected that there are still some active free radicals at the end of deposition. When a heating is applied after the first cooling, it is possible of production of new crosslinking by the effect of temperature. Thus, at second cooling the crosslinking density may be more than the crosslinking density at first cooling. This difference can be clearly observed with the difference between dielectric constants as shown in Table $1 \mathrm{a}, \mathrm{b}$.

Table 1. Dielectric constant for different thicknesses at a) first cooling, b) second cooling.

a

\begin{tabular}{|c|c|}
\hline Sample & $\begin{array}{c}\text { Dielectric } \\
\text { constant }\end{array}$ \\
\hline $20 \mathrm{~nm}$ & 5,3 \\
\hline $100 \mathrm{~nm}$ & 9,9 \\
\hline $250 \mathrm{~nm}$ & 12,9 \\
\hline $500 \mathrm{~nm}$ & 12,8 \\
\hline
\end{tabular}

b

\begin{tabular}{|c|c|}
\hline Sample & $\begin{array}{c}\text { Dielectric } \\
\text { constant }\end{array}$ \\
\hline $20 \mathrm{~nm}$ & 5 \\
\hline $100 \mathrm{~nm}$ & 7,3 \\
\hline $250 \mathrm{~nm}$ & 11,7 \\
\hline $500 \mathrm{~nm}$ & 11,4 \\
\hline
\end{tabular}


Dielectric loss exhibits two relaxation regions in the investigated frequency range as shown in Fig. 3 and Fig. 4. The relaxation which is observed at low frequencies so called $\alpha$ relaxation can be attributed to dynamic glass transition. The other relaxation so called $\beta$ relaxation can be attributed to dipolar fluctuations [21-24]. These relaxation regions shift toward high frequencies with increasing temperature as shown in Fig. 3 a, b, c, d and Fig. 4 a, b, c, d. This behavior may be attributed that the motion of $\alpha$ and $\beta$-relaxations can follow the applied electric field at higher frequencies with increasing temperature [25, 26].
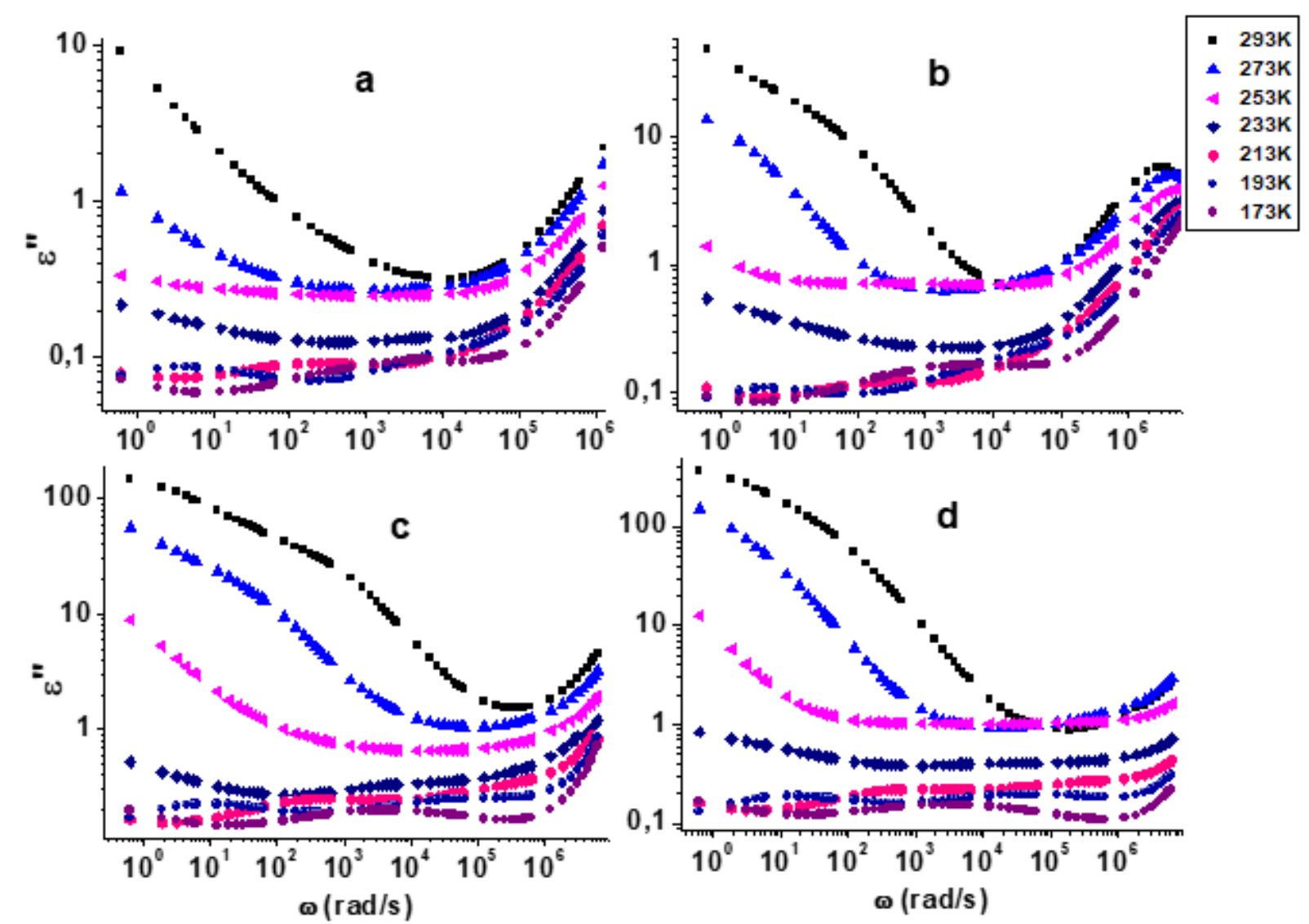

Figure 3. Frequency dependence of dielectric loss $\left(\varepsilon^{\prime \prime}\right)$ for a) $\left.\left.20 \mathrm{~nm}, \mathrm{~b}\right) 100 \mathrm{~nm}, \mathrm{c}\right) 250 \mathrm{~nm}$, d) $500 \mathrm{~nm}$ at first cooling process.

At second cooling process, the temperatures at which $\alpha$-relaxation observed shift toward low temperatures with decreasing thickness as shown in Fig. 4 a, b, c, d. When the thickness of the samples decreases, the effect of dead layer may be pronounced and as a result of this $\alpha$ relaxation can't follow the applied field at higher frequencies. 

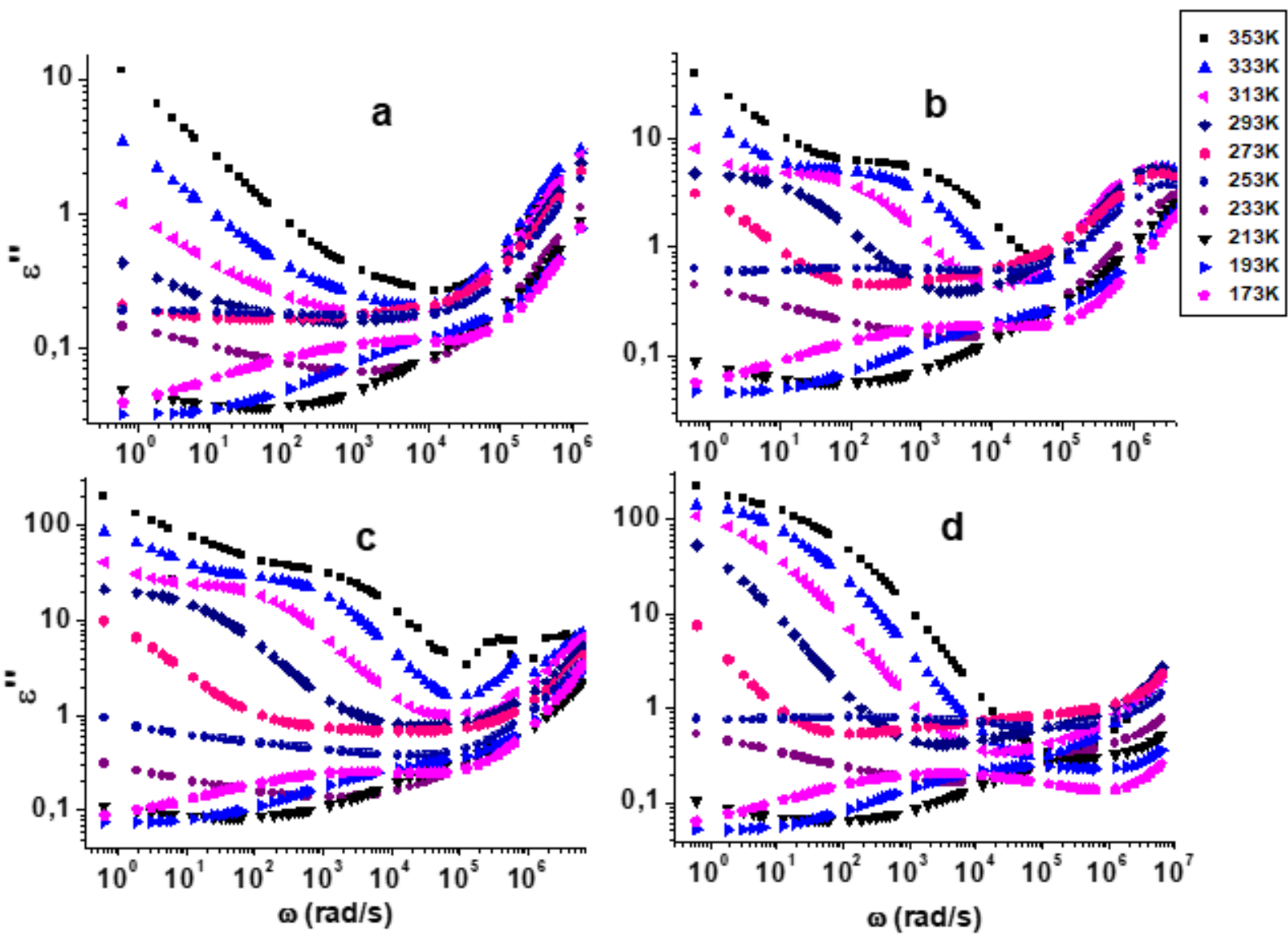

Figure 4. Frequency dependence of dielectric loss ( $\left.\varepsilon^{\prime \prime}\right)$ for a) $20 \mathrm{~nm}$, b) $100 \mathrm{~nm}$, c) $250 \mathrm{~nm}$, d) $500 \mathrm{~nm}$ at second cooling process.

When the frequencies at which maximum dielectric loss observed are fitted by VogelFulcher-Taman equation, dynamic glass transition temperatures were calculated by equation below [1],

$$
f_{p, \alpha}=f_{\infty} \exp \left[-\frac{B}{T-T_{0}}\right]
$$

Glass transition temperature increases with decreasing thickness. The calculated glass transition temperatures and a representative graph showing the relation between peak frequencies and temperature are shown in Table 2.

Table 2. Dynamic glass transition temperatures at heating and second cooling processes.

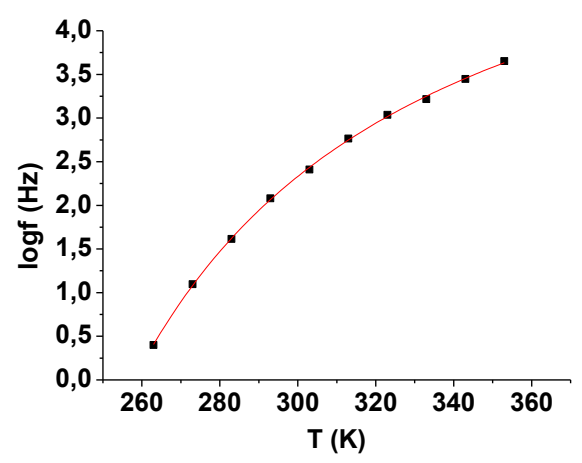

\begin{tabular}{|c|c|c|}
\hline Sample & $\begin{array}{c}\text { To } \\
\text { (Heating) }\end{array}$ & $\begin{array}{c}\text { To (Second } \\
\text { cooling) }\end{array}$ \\
\hline $20 \mathrm{~nm}$ & $242 \mathrm{~K}$ & $282 \mathrm{~K}$ \\
\hline $100 \mathrm{~nm}$ & $195 \mathrm{~K}$ & $201 \mathrm{~K}$ \\
\hline $250 \mathrm{~nm}$ & $196 \mathrm{~K}$ & $200 \mathrm{~K}$ \\
\hline $500 \mathrm{~nm}$ & $174 \mathrm{~K}$ & $211 \mathrm{~K}$ \\
\hline
\end{tabular}


It is observed that glass transition temperature increases with decreasing thickness. Plasma polymers have adhesion ability onto substrates. The adhesion layer so called dead layer is the most adhesive layer of structure. Dead layer has more fluency on thin film if the thickness is low. The low dielectric constant for thinner films supports the presence of dead layer [27, 28].

\section{CONCLUSION}

Frequency, temperature and thickness dependence of dielectric properties of pPEO thin film samples at first cooling and second cooling processes. It was observed that the crosslinking density has influence on dielectric properties. At second cooling process, it was observed by decreasing dielectric constant and increasing glass transition temperatures. This change was attributed to increasing crosslinking density due to catalyzing effect of temperature on free radicals. It is thought that more free radicals reacted with each other and raised the number of crosslinking by the effect of temperature. The glass transition temperatures were calculated using the relation between peak frequencies at which maximum dielectric loss observed and temperature. The calculated glass transition temperatures exhibit a behavior associated with interpretation about dead layer approximation as mentioned in literature. This association gives us an idea that we can use dielectric spectroscopy and VFT equation to determine glass transition temperature in thin film form.

\section{ACKNOWLEDGEMENT}

The work is financially supported by Scientific Research Projects Unit of Istanbul University with project number 3569, 52926 and 21764.

\section{REFERENCES}

[1]. S. Diaham, M.L. Locatelli, T. Lebey, S. Dinculescu, Dielectric measurements in large frequency and temperature ranges of an aromatic polymer, Eur. Phys. J. Appl. Phys., 49 (2010) 10401 1-7.

[2]. E. Neagu, P. Pissis, L. Apekis, J. L. G. Ribelles, Dielectric relaxation spectroscopy of polyethylene terephthalate (PET) films, J. Phys. D: Appl. Phys., 30 (1997) 1551-1560.

[3]. N. Gondaliya, D. K. Kanchan, P. Sharma, M. S. Jayswal, M. Pant, Conductivity and dielectric behavior of $\mathrm{AgCF}_{3} \mathrm{SO}_{3}$ doped PEO polymer films, Integrated Ferroelectrics, 119 (2010) 1-12.

[4]. P. Saxena, M. S. Gaur, P. Shukla, P. K. Khare, Relaxation investigations in polysulfone: Thermally stimulated discharge current and dielectric spectroscopy, Journal of Electrostatics, 66 (2008) 584-588.

[5]. A. A. Hashim in Polymer Thin Films, A A Hashim, Eds., In-The, Vukovar, Croatia, 2010, p1-4.

[6]. S. Islam, G. B. V. S. Lakshmi, A. M. Siddiqui, M. Husain, M. Zulfequar, Synthesis, electrical conductivity and dielectric behavior of polyaniline $/ \mathrm{V}_{2} \mathrm{O}_{5}$ composites, International Journal of Polymer Science, Article ID 307525 (2013) 7 pages.

[7]. S. Saravanan, C. J. Mathai, S. Venkatachalam, M. R. Anantharaman, Low $k$ thin films based on RF plasmapolymerized aniline, New Journal of Physics, 6 (2004) 64.

[8]. A. Choukourov, I. Gordeev, O. Polonskyi, A. Artemenko, L. Hanykova, I. Krakovsky, O. Kylian, D. Slavinska, H. Biederman, Polyethylene (ethylene oxide)like plasma polymers produced by plasmaassisted vacuum evaporation, Plasma Process. Polym., 7 (2010) 445-458. 
[9]. C. J. Mathai, S. Saravanan, M. R. Anantharaman, S. Venkitachalam, S. Jayalekshmi, Characterization of low dielectric constant polyaniline thin film synthesized by ac plasma polymerization technique, J. Phys. D: Appl. Phys., 35 (2002) 240-245.

[10].T. Afroze, A. H. Bhuiyan, Alternating current electrical properties of thin films of plasma polymerized $1,1, \quad 3, \quad 3-$ tetramethoxypropane, Advances in Polymer Technology, 33 (2014) 1-4.

[11].D. S. Kumar, Y. Yoshida, Dielectric properties of plasma polymerized pyrrole thin film capacitors, Surface and Coatings Technology, 169 -170 (2003) 600-603.

[12].F. U. Z. Chowdhury, A. H. Bhuiyan, Dielectric properties of plasmapolymerized diphenyl thin films, Thin Solid Films, 370 (2000) 78-84.

[13].X. Y. Zhao, M. Z. Wang, Z. Wang, Deposition of plasma-polymerized 1cyanoisoquinoline thin films and their dielectric properties, Plasma Process. Polym., 4 (2007) 840-846.

[14].H. Jiang, L. Hong, N. Venkatasubramanian, J. T. Grant, K. Eyink, K. Wiacek, S. Fries-Carr, J. Enlow, T. J. Bunning, The relationship between chemical structure and dielectric properties of plasma-enhanced chemical vapor deposited polymer thin films, Thin Solid Films, 515 (2007) 3513-3520.

[15].A. Choukourov, A. Grinevich, O. Polonskyi, J. Hanus, J. Kousal, D. Slavinska, H. Biederman, Vacuum Thermal Degradation of Poly(ethylene oxide), Journal of Physical Chemistry B, 113 (2009) 2984-2989.

[16].C. Changrok, O.C. Kun, J. Donggeun, W.M. Dae, G.L. Tae, Surface characterization of plasma-polymerized polyethylene glycol thin film modified by plasma treatment, Surface and Interface Analysis, 45 (2013) 220-224.

[17].B. Sannakki and Anita, Dielectric Properties of PMMA and its composites with ZrO2, Physics Procedia, 49 (2013) 15 $-26$.

[18].A.P. Singh, Y.P. Singh, Dielectric behavior of $\mathrm{CoCu}_{3} \mathrm{Ti}^{4} \mathrm{O}_{12}$ :Poly Vivyl Chloride ceramic polymer composites at different temperature and frequencies, Modern Electronic Materials, 2 (2016) 121-126.

[19].D. Değer ve K. Ulutaş, Conduction and Dielectric polarization in Se Thin Films, Vacuum, 72 (2004) 307- 312.

[20].K. Se, K. Adachi, T. Kotaka, Dielectric Relaxations in Poly (ethyleneoxide): Dependence on Molecular Weight, Polymer Journal, 13 (1981) 1009-1017.

[21].E. Sardella, R. Gristina, G.S. Senesi, R. d'Agostino, P. Favia, Homogeneous and Micro-Patterned Plasma-Deposited PEOLike Coatings for Biomedical Surfaces, Plasma Processes and Polymers, 1 (2004) 63-72.

[22].Y.J. Wu, R.B. Timmons, J.S. Jen, F.E. Molock, Non-fouling surfaces produced bygas phase pulsed plasma polymerization of an ultralow molecular weight ethylene oxide containing monomer, Colloids and Surfaces B:Biointerfaces, 18 (2000) 235248.

[23].K.E. Bremmell, P. Kingshott, Z. Ademovic, B. Winther-Jensen, H.J. Griesser, Colloid Probe AFM Investigation of Interactions between Fibrinogen and PEG-Like Plasma Polymer Surfaces, Langmuir, 22 (2006) 313-318.

[24].F. Palumbo, Favia, M. Vulpio, R. d'Agostino, RF Plasma Deposition of PEO-Like Films: Diagnostics and Process Control, Plasmas and Polymers, 6-3 (2001) 163-174.

[25].Ş. Yakut, K. Ulutaş, I. Melnichuk, A. Choukourov, H. Biederman, D. Değer, Dielectric properties of plasma polymerized poly(ethylene oxide) thin films, Thin Solid Films, 616 (2016) 279286.

[26].S. Yakut, K. Ulutas, D. Deger, Plasma discharge power dependent AC conductivity of plasma poly(ethylene 
oxide) thin films, Thin Solid Films, 645

(2018) 269-277.

[27].D. Prevosto, S. Napolitano, P. Pingue, S. Capaccioli, and M. Lucchesi, Investigation of structural relaxationand surface modification of ultrathin filmsof poly(ethylene terephthalate), European Physical Journal-Special Topics, 141 (2007) 193-198.

[28].S. Napolitano, D. Prevosto, M. Lucchesi, P. Pingue, M. D'Acunto, and P. Rolla, Influence of a Reduced Mobility Layer on the Structural Relaxation Dynamics of Aluminum Capped Ultrathin Films of Poly (ethyleneterephthalate), Langmuir, 23 (2007) 2103-2109 